\title{
THE
}

$12-3-2013$

\section{Comparing sediment equilibrium partitioning and passive sampling techniques to estimate benthic biota PCDD/F concentrations in Newark Bay, New Jersey (U.S.A.)}

\author{
Carey L. Friedman \\ Rainer Lohmann \\ University of Rhode Island, rlohmann@uri.edu
}

Follow this and additional works at: https://digitalcommons.uri.edu/gsofacpubs

The University of Rhode Island Faculty have made this article openly available.

Please let us know how Open Access to this research benefits you.

This is a pre-publication author manuscript of the final, published article.

Terms of Use

This article is made available under the terms and conditions applicable towards Open Access

Policy Articles, as set forth in our Terms of Use.

\section{Citation/Publisher Attribution}

Friedman, C. L., \& Lohmann, R. (2014). Comparing sediment equilibrium partitioning and passive sampling techniques to estimate benthic biota PCDD/F concentrations in Newark Bay, New Jersey (U.S.A.).

Environmental Pollution, 186, 172-179. doi: 10.1016/j.envpol.2013.12.002

Available at: https://doi.org/10.1016/j.envpol.2013.12.002

This Article is brought to you for free and open access by the Graduate School of Oceanography at DigitalCommons@URI. It has been accepted for inclusion in Graduate School of Oceanography Faculty Publications by an authorized administrator of DigitalCommons@URI. For more information, please contact digitalcommons-group@uri.edu. 
1 Comparing sediment equilibrium partitioning and passive sampling techniques to estimate

2 benthic biota PCDD/F concentrations in Newark Bay, New Jersey (U.S.A.)

4 Carey L. Friedman ${ }^{\mathrm{a} 1 *}$ and Rainer Lohmann ${ }^{\mathrm{a}}$

$6{ }^{a}$ University of Rhode Island Graduate School of Oceanography (URI-GSO), University of Rhode

7 Island Bay Campus, 215 South Ferry Road, Narragansett, RI 02882 USA

8 Telephone: 401-874-6612

9 Fax: 401-874-6811

$10 *$ Corresponding author (clf@mit.edu)

11

${ }^{1}$ C.L. Friedman's current address is Center for Global Change Science, MIT E19-411n, 77 Massachussetts Ave. Cambridge, MA, USA 02139. 


\section{ABSTRACT}

13 Sediment and polyethylene sampler-based estimates of polychlorinated dibenzo- $p$ -

14 dioxin/dibenzofuran (PCDD/F) concentrations in Newark Bay, New Jersey (USA) benthic biota

15 were compared. Biota concentrations based on sediment were estimated using an organic carbon

16 (OC)-water partitioning model and an OC and black carbon (BC)-water dual model. Biota

17 concentrations based on polyethylene were estimated from samplers deployed in the Newark Bay

18 water column and samplers immersed in a sediment/porewater slurry in the laboratory.

19 Porewater samplers provided the best estimates of biota concentrations (within 3.1x), with best

20 results achieved for deposit-feeders (within 1.6x). Polyethylene deployed in deep water also

21 provided good estimates of biota concentrations (within 4x). By contrast, OC-water partitioning

22 overestimated biota concentrations by up to 7x, while $\mathrm{OC}$ and $\mathrm{BC}$ combined underestimated

23 biota concentrations by up to $13 x$. We recommend polyethylene for estimating concentrations of

24 hydrophobic organic contaminants in field biota given its simplicity and relatively lower

25 uncertainty compared to sediment equilibrium partitioning.

27 Capsule: Using polyethylene samplers to measure porewater concentrations is a more efficient 28 approach for estimating site-specific bioavailable organic contaminants than equilibrium 29 partitioning.

31 Key Words: polyethylene, equilibrium partitioning, PCDD, Newark 
INTRODUCTION

Polychlorinated dibenzo-p-dioxins and dibenzofurans (PCDD/Fs) are toxic hydrophobic organic contaminants (HOCs) that sorb to particles in sediments (Luthy et al., 1997).

36 Sedimentary HOCs can be bioavailable to benthic marine organisms and accumulate up the

37 marine food chain (DeWit et al., 1995; Pickard and Clarke, 2008). The risk of aquatic organism

38 exposure to HOCs is a primary consideration when choosing an approach to clean-up HOC-

39 contaminated sites. One such site is the lower Passaic River/Newark Bay in New Jersey (USA).

40 The lower Passaic is the location of the former Diamond Alkali pesticide manufacturing

41 company, which discharged waste to adjacent waters during the 1950s/60s, severely

42 contaminating sediments with PCDD/Fs. In 1984, the sediment site was added to the U.S. EPA

43 Superfund list and is currently undergoing a two-phase clean-up process that will include

44 removal of $153,000 \mathrm{~m}^{3}$ of sediment via dredging (US EPA). Newark Bay, one of the most

45 industrialized estuaries in the United States, extends just south of the Passaic (Fig. 1) and is

46 known to be impacted by PCDD/Fs from the Passaic (Rappe et al., 1991). Though there have

47 been efforts to characterize contaminant dynamics in the Passaic River and Newark Bay, passive

48 sampling, a promising state-of-the-art method for determining dissolved HOC concentrations

49 (Choi et al., 2013; Fernandez et al., 2009), has not been employed. In this study, we compare

50 passive sampling-based estimates of PCDD/F concentrations in sediment-dwelling biota, and

51 conventional equilibrium partitioning-based estimates using sediment geochemical

52 characteristics (i.e., organic and black carbon, $\mathrm{OC}$ and $\mathrm{BC}$ ) to PCDD/F concentrations measured

53 in biota collected from Newark Bay.

54 Passive samplers of various types have been used as tools to directly sample porewater

55 dissolved HOCs, or as surrogates for bioaccumulation organisms (Adams et al., 2007; Huckins et 
56 al., 1990; Lohmann et al., 2004; Mayer et al., 2000; Schneider et al., 2006; Vinturella et al.,

57 2004). Passive samplers circumvent problems associated with traditional solvent-based

58 porewater extractions by sampling freely dissolved HOCs via diffusive uptake into the sampler

59 matrix and thus avoiding the need to isolate interstitial water and having to address related

60 artifacts. In a previous study by our group, a laboratory bioaccumulation study with field-

61 contaminated sediment demonstrated that polyethylene (PE) passive samplers can estimate freely

62 dissolved PCB concentrations organisms are exposed to within a factor of four (Friedman et al.,

63 2009). Others have similarly shown that PE can be useful for predicting uptake of PAHs in

64 benthic biota in the laboratory (Vinturella et al., 2004). PE and other samplers have also been

65 useful in determining the direction of HOC fluxes between environmental compartments; for

66 example, from the water column to the atmosphere (Morgan and Lohmann, 2008) or from

67 porewater to the overlying water column (Cornelissen et al., 2008). Only a limited number of

68 studies have demonstrated the utility of PE in predicting HOC body burdens of organisms in the

69 field, however (Cho et al., 2009).

70 In contrast, a number of studies have discussed and used equilibrium partitioning from

71 sediment $\mathrm{OC}$, and several from $\mathrm{OC}$ and $\mathrm{BC}$ combined, to predict freely dissolved HOC

72 concentrations and, by extension, bioavailability (Accardi-Dey and Gschwend, 2002, 2003;

73 Burgess et al., 2013; DiToro et al., 1991; Hawthorne et al., 2007a; Hawthorne et al., 2006,

74 2007b; Lohmann et al., 2005). In general, OC-water-based equilibrium partitioning

75 overestimates dissolved concentrations (Hawthorne et al., 2006; Lohmann et al., 2005), and

76 mixed results are reported when other sediment carbon phases like BC are considered, with some

77 studies showing improvements to estimates (Accardi-Dey and Gschwend, 2003; Lohmann et al.,

78 2005), and others showing little change or underestimates (Hawthorne et al., 2007a; Hawthorne 
79 et al., 2007b). Often these estimate errors are considered to result from inadequate equilibrium

80 partition coefficient values.

81 Here, we compare biota PCDD/F concentrations estimated from equilibrium partitioning

82 between sedimentary carbon phases and porewater to those measured in organisms collected

83 directly from the Newark Bay. The specific goals of the study are to determine whether (i) PE

84 are useful in predicting benthic biota PCDD/F burdens in the field; (ii) PE-based porewater

85 and/or water column dissolved concentrations are better predictors of in-situ bioaccumulation

86 than sediment equilibrium partitioning; and, (iii) including BC in partitioning calculations

87 substantially impacts estimated biota concentrations. We address these goals by collecting and

88 analyzing Newark Bay sediment, porewater, and biota, and by deploying PE samplers directly in

89 the Bay.

90 
91 MATERIALS AND METHODS

92 Site Description and Overall Methodology

93 Newark Bay, ( 1.5 km wide, $10 \mathrm{~km}$ long), is part of the New York/New Jersey Harbor

94 Estuary (Fig. 1). The Bay converges with the Passaic and Hackensack Rivers at its north and the 95 Arthur Kill (“AK”) and Kill van Kull ("KVK”) at its south. The Passaic and the Hackensack

96 Rivers are sources of freshwater to Newark Bay with a combined watershed of $3000 \mathrm{~km}^{2}$, though

97 the Hackensack is estimated to contribute only 7\% of the Passaic River on average (Caplow et

98 al., 2003).

99 Five sites were chosen throughout the Bay for sampling (Fig. 1). The "Passaic",

100 "Hackensack", "AK", and "KVK" sites represent locations where the Bay converges with each

101 water channel. The mid-Bay ("MB") site was located in the middle of Newark Bay. Water

102 column depths were $\sim 1.5 \mathrm{~m}$ at the Passaic, Hackensack, and MB stations, $4 \mathrm{~m}$ at the KVK, and

$1038.8 \mathrm{~m}$ at the AK station. Sediment and biota were collected from each site and analyzed for

$104 \mathrm{PCDD} /$ Fs. Porewater was also analyzed for PCDD/Fs by tumbling PE and sediment together in

105 glass flasks on a shaker table in the laboratory. A separate set of PE samplers was deployed in-

106 situ at each site to determine dissolved PCDD/F concentrations above the sediment bed ("deep

107 water"). PCDD/F concentrations from all media were then converted to tissue concentrations

108 using equilibrium partition coefficients, and estimated tissue concentrations were compared to

109 those measured directly from biota. Concentrations in porewater and deep water PE were also

110 compared to determine the direction of the diffusive flux of PCDD/Fs across the sediment-water

111 interface. All extraction procedures and instrumental methods are detailed in the SI (SI text and

112 Table S1). 
115 Sediment and biota were collected from the R/V Kenneth Biglane using a van Veen grab.

116 From each grab, $\sim 250 \mathrm{~mL}$ of sediment was collected from the top half $(\sim 10 \mathrm{~cm})$ and stored on

117 ice. The remainder of the grab was rinsed through a $1 \mathrm{~mm}$ sieve. Clams (Mya arenaria) and

118 deposit-feeding tube worms (Pectinaria gouldii) remaining on the sieve were collected and

119 depurated in seawater in plastic bags for 4-8 hours at field temperature. Collections were

120 repeated until several grams of tissue had been collected. Biota were rinsed with tap water,

121 placed in muffled amber jars, and frozen on dry ice.

Preparation of PEs for field deployment and laboratory tumbling experiments

124 Sheets of PE painter's drop cloth $(25 \mu \mathrm{M}$ thickness, Covalence Plastics) were cut into $\sim 1$

$125 \mathrm{~g}$ pieces and cleaned by submersing in dichloromethane for $24 \mathrm{~h}$ twice. To gauge the equilibrium

126 status of analytes in deep water PE, performance reference compounds (PRCs) were added to PE

127 samplers before deployment. PRCs used for all analytes included $\mathrm{d}_{10^{-}}$anthracene, $\mathrm{d}_{12^{-}}$

128 benz[a]anthracene, and octachloronapthalene (Ultra Scientific; Cambridge Isotopes). These

129 compounds were chosen because of their similar planar conformation to PCDD/Fs, and because

130 isotopically-labeled PCDD/Fs were employed as internal standard surrogates in all extractions.

131 Thus, the assumption was made that PCDD/Fs are taken up into PE at the same rate that PRCs

132 dissipate from PE (Huckins et al., 2002). This assumption introduces uncertainty into deep water

133 concentrations, addressed later in the Results. Polyethylene pieces were impregnated with PRCs

134 in an 80:20 methanol:water solution following previously published methods (Booij et al., 2002).

135 The methanol:water solution was spiked with $1 \mu \mathrm{g}$ PRC per $1 \mathrm{~g}$ sampler and samplers were

136 immersed in the solution for 8-12 weeks to ensure homogeneous distribution. Samplers were 
137 removed from the PRC solution and wiped dry with laboratory-grade tissues. A small snippet

138 ( 0.1 g) was cut from each sampler for initial PRC analysis $\left(\mathrm{C}_{\mathrm{PRC}, \mathrm{t}=0}\right)$. For field deployments, the

139 remainder of the sampler was strung on pre-cleaned stainless steel wire (Malin Co.), wrapped in

140 aluminum foil, and both snippet and sampler were stored at $-4^{\circ} \mathrm{C}$ until deployment or analysis.

$142 \quad$ PE-porewater tumbling experiments

143 Three different sized samplers were cut from PRC-impregnated PE $(\sim 0.25,0.50$, and 0.75

$144 \mathrm{~g}$ ) for each sampling location. This was done to assess whether PEs had reached equilibrium with 145 porewater during tumbling, and sizes were chosen such that PCDD/Fs were not depleted from 146 the sediment-porewater system (calculation in the SI). Samplers were added to $125 \mathrm{~mL}$ muffled 147 round bottom flasks with 50-60 $\mathrm{g}$ wet sediment. Ten $\mathrm{mL}$ of $1 \mathrm{mg} / \mathrm{mL}$ sodium azide was added to 148 each flask to limit bacterial growth, and flasks were filled to air-tight level with Milli-Q water.

149 PEs were left to tumble with sediments in the dark on a shaker table at room temperature $\left(24^{\circ} \mathrm{C}\right)$

150 for eight weeks, sufficient for PCDD/Fs to reach equilibrium as per previous work in our group

151 (Lambert et al., 2011).

Deep water PE-field deployments

154 Three replicate PE samplers were deployed from June 16 to July 6, 2009 at the same sites 155 as sediment and tissue collection (Fig. 1). Samplers were deployed at the bottom of the water 156 column using cement cinder blocks attached to a line and buoy, and PE were placed $\sim 30 \mathrm{~cm}$ 157 above the sediment bed. After every 10 deployments, a clean PE sampler was exposed to 158 ambient air momentarily and collected as a field blank. After collection, all PEs were wrapped in 
159 clean aluminum foil, stored on ice, and returned to the laboratory. Samplers were deployed and

160 collected from the R/V Kenneth Biglane.

161

162 Adjustments to concentrations

163 To adjust field-deployed deep water PE concentrations for disequilibrium, linear

164 relationships were determined between $\mathrm{PRC}$ fraction equilibrium reached $\left(\mathrm{f}_{\mathrm{EQ}}\right)$ and $\mathrm{PRC}$

165 molecular weight (MW) for each set of PEs undergoing the same sampling scheme (i.e.,

166 replicates deployed at the same site or in the same tumbling experiment):

$$
f_{E Q}=m(M W)+b
$$

168 where $\mathrm{m}$ is the slope, $\mathrm{b}$ is the intercept and $\mathrm{f}_{\mathrm{EQ}}$ is determined as:

$$
f_{E Q}=1-\frac{C_{P R C, t}}{C_{P R C, t=0}}
$$

170 where $\mathrm{C}_{\mathrm{PRC}, \mathrm{t}}$ is the concentration of a PRC in PE at time t. The mean p-value for statistical

171 correlation between $\mathrm{MW}$ and $\mathrm{f}_{\mathrm{EQ}}$ was 0.04 . The linear relationships were then used with PCDD/F

172 MW to estimate each analyte's equilibrium status, and $\mathrm{C}_{\mathrm{PEdw}} \mathrm{s}$ were adjusted as follows:

$$
C_{P E d w, \infty}=\frac{C_{P E d w}}{f_{E Q}}
$$

174 where $\mathrm{C}_{\mathrm{PEdw}, \infty}$ is the concentration in deep water PE adjusted to $100 \%$ equilibrium. Using this

175 method, PCDD/Fs in deep water PE had reached between $73 \%$ and $98 \%$ equilibrium. No

176 concentration adjustments were made to PEs tumbled with sediment, as equilibrium was

177 determined by comparing concentrations in different sized samplers. 
Activity gradients are defined as the equilibrium concentration in the deep water PE

$181\left(\mathrm{C}_{\mathrm{PEdw}, \infty}\right)$ divided by the equilibrium concentration in the porewater $\mathrm{PE}\left(\mathrm{C}_{\mathrm{PEpw}, \infty}\right)$ for the same

182 compound at a given sampling site. To derive activity gradients at sites where a compound was

183 detected in only one PE of the pair, one-half of the analytical detection limit was substituted for

184 zero to calculate a ratio. Uncertainties introduced by this substitution are discussed in the

185 Results.

Estimating biota HOC uptake

Lipid concentrations (ng/g) were estimated from each sorbent phase (OC, OC+BC,

189 porewater $\mathrm{PE}$, and deep water $\mathrm{PE})$ and compared to those measured in tissues $\left(\mathrm{C}_{\text {lip }}\right)$. Lipid

190 concentrations were estimated from sediment $\mathrm{OC}$ partitioning $\left(\mathrm{C}_{\mathrm{lip}, \mathrm{OC}}\right)$ as the product of

191 dissolved concentrations (ng/mL) and the bioaccumulation factor (BAF; unitless) as follows:

192

$$
C_{l i p, O C}=C_{d i s s, O C} B A F=\frac{C_{s e d} B A F}{f_{O C} K_{O C}}
$$

193 where $\mathrm{C}_{\text {sed }}$ is the HOC concentration in the sediment (ng/g), $\mathrm{f}_{\mathrm{OC}}$ is the fraction of OC in the

194 sediment, and $K_{\mathrm{OC}}$ is the OC-water partition coefficient (mL water/g OC). $K_{\mathrm{OC}}$ f for PCDD/Fs

195 were derived from the literature (Xia, 1998), while PCDD/F BAFs were estimated from PCDD/F

196 octanol-water partition coefficients $\left(\mathrm{K}_{\mathrm{OWS}}\right)$, using a regression determined with PAH data at 5-

$19724^{\circ} \mathrm{C}$ (Muijs and Jonker, 2009). Uncertainties associated with the BAF estimation are discussed

198 later.

Similarly, lipid concentrations based on sediment $\mathrm{OC}$ and $\mathrm{BC}\left(\mathrm{C}_{\mathrm{diss}, \mathrm{OC}+\mathrm{BC}}\right)$ were estimated

201 as the product of the BAF and dissolved concentrations (Accardi-Dey and Gschwend, 2002)

202 using a Freundlich coefficient of $\mathrm{n}=0.7$ : 


$$
C_{l i p, O C+B C}=C_{d i s s, O C+B C} B A F=\frac{C_{s e d} B A F}{f_{O C} K_{O C}+f_{B C} K_{B C} C_{d i s s}^{n-1}}
$$

204 where $\mathrm{f}_{\mathrm{BC}}$ is the fraction of $\mathrm{BC}$ in the sediment and $K_{\mathrm{BC}}$ is the $\mathrm{BC}$-water partition coefficient

205 (mL water/g BC). Both literature and sediment-specific values of $K_{\mathrm{BC}}$ were used to calculate

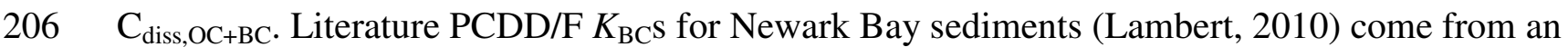

207 adjacent field location (the Passaic River) approximately $200 \mathrm{~cm}$ deeper into the sediment bed.

208 Sediment-specific $K_{\mathrm{BC}}$ were derived from porewater dissolved PCDD/F concentrations

209 calculated from PE samplers in the present study using equation 5 (with $n=0.6,0.7$, and 0.8 ).

211 Lastly, lipid concentrations from porewater $\left(\mathrm{C}_{\text {lip,PEpw }}\right)$ and deep water $\left(\mathrm{C}_{\text {lip,PEdw }}\right)$ were

212 estimated from PE uptake as follows:

$$
C_{l i p, P E}=C_{d i s, P E} B A F=\frac{C_{P E, \infty} B A F}{K_{P E-w}}
$$

214 where $K_{\mathrm{PE}-\mathrm{w}}$ is the $\mathrm{PE}$-water partition coefficient ( $\mathrm{mL}$ water/g PE) estimated from $\mathrm{K}_{\mathrm{OW}}$ (Adams

215 et al., 2007). Values of $K_{\mathrm{OW}}$ were taken from Aberg et al. (2008). $K_{\mathrm{PE}-\mathrm{w}} \mathrm{s}$, determined at $24^{\circ} \mathrm{C}$ and

$2160 \mathrm{ppt}$ salinity, were adjusted to reflect deep water and porewater temperature and salinity

217 conditions. See the SI for additional information regarding physicochemical constants used for 218 temperature and salinity adjustments.

\section{Sediment total organic carbon and black carbon}

221 For total organic carbon (TOC) determinations, sediments were dried at $60^{\circ} \mathrm{C}$, ground 222 after shell material was removed, treated with $\mathrm{HCl}$, and analyzed for $\% \mathrm{C}$ on a Carlo Erba NA 2231500 elemental analyzer (Fisons Instruments, Beverly, MA, USA) coupled to a VG-Optima 224 stable isotope mass spectrometer. BC was determined using previously published methods 
225 (Accardi-Dey and Gschwend, 2002; Gustafsson et al., 1996). National Institute of Standards and

226 Technology Standard Reference Material 1941b analyzed with this method had a mean BC

227 content of $0.57 \pm 0.01 \%(n=3)$, just within the range $(0.6-19.7)$ presented by a comprehensive

228 BC quantification method intercomparison study (Hammes et al., 2007). Amorphous organic

229 carbon (i.e., the fraction of TOC not considered BC) was determined by subtracting the fraction 230 of BC from TOC.

231 


\section{RESULTS AND DISCUSSION}

233 Sediment

Sediment OC ranged from 1.6 to $5.8 \%$ and sediment BC ranged from 0.2 to $0.3 \%$ (Table

235 S2), comparable to previous results for $\mathrm{OC}$ and $\mathrm{BC}$ of $2.6 \%$ and $0.3 \%$ in New York Harbor

236 (Lohmann et al., 2005). Sediment concentrations ranged from $0.1(1,2,3,4,7,8-\mathrm{HxCDF}$ in the

$237 \mathrm{AK}$ ) to $76 \mathrm{ng} / \mathrm{g}$ OC (OCDD in the AK), or 0.005 to $2.4 \mathrm{ng} / \mathrm{g}$ dry (Figs. S1 and S2). At all sites,

238 OCDD was present in the greatest concentrations followed by 2,7/2,8-DiCDD. Several of the

239 mid-MW congeners (2,3,7,8-TCDF, 1,2,3,7,8-PeCDF, 2,3,4,7,8-PeCDF) were only detected in

240 the northern half of the Bay in the Passaic and Hackensack Rivers. The most toxic dioxin

241 congener, 2,3,7,8-TCDD, was present at all sites, but was most concentrated in the Passaic and

242 Hackensack $(2.1 \pm 0.8 \mathrm{ng} / \mathrm{g}$ OC and $2.1 \pm 0.9 \mathrm{ng} / \mathrm{g} \mathrm{OC}$, respectively). We compared 2,3,7,8-

243 TCDD concentrations from the present study to those found during the Contaminant Assessment

244 and Reduction Project (CARP), which measured 2,3,7,8-TCDD sediment concentrations in the

245 AK in the late 1990s/early 2000s (CARP, 2007). Concentrations of 2,3,7,8-TCDD there ranged

246 from 0.02 to $0.08 \mathrm{ng} / \mathrm{g}$, similar to AK dry weight concentrations determined in the present study

$247 \quad(0.020 \pm 0.004 \mathrm{ng} / \mathrm{g})$.

249 Tissue

250 The mean lipid content of deposit feeders was $0.07 \mathrm{~g} / \mathrm{g}$ dry weight, while that of filter

251 feeders was $0.04 \mathrm{~g} / \mathrm{g}$. Lipid-normalized tissue concentrations shown are from deposit-feeding

252 tube worms (Pectorina gouldii) in the AK and filter-feeding clams (Mya arenaria) in the

253 Passaic, Hackensack, MB, and KVK (Fig. S3). Tube worms from the AK had detectable

254 concentrations of a full suite of mono- through octa-CDD/Fs (from 2.6 to $49 \mathrm{ng} / \mathrm{g}$ lipid), whereas 
255 filter-feeding clams had no detectable levels of high MW PCDD/Fs (i.e., hexa- through octa-

$256 \mathrm{CDD} / \mathrm{Fs})$. The difference in high MW uptake by tissues is probably a reflection of feeding mode

257 differences, given that sediments from all sites had fairly high concentrations of hepta- and octa-

258 CDD/Fs. A difference in uptake among organisms with feeding modes has been observed

259 previously, with deposit-feeders receiving the majority of their HOC burden through sediment

260 ingestion and filter-feeders receiving roughly equal amounts from sediment ingestion and water

261 filtration (McLeod et al., 2008). Low MW congener tissue concentrations were similar across

262 sites and different feeding modes, except for clams in the Passaic and Hackensack, wherein only

263 one congener (1,2,3,7,8-PeCDF) was detected, primarily due to low biota masses collected at

264 these sites. The only tissue sample in which 2,3,7,8-TCDD was detected was AK tube worms

265 (3.2 ng/g lipid), with concentrations similar to those found in ribbed mussels (Modiolis demissus)

266 from the Passaic and Newark Bay during the CARP study $(1.2-3.5 \mathrm{ng} / \mathrm{g}$ lipid and $0.62-1.4$

267 ng/g lipid, respectively) (CARP, 2007).

268

269 Deep water and porewater

270 Dissolved PCDD/Fs detected in deep water ranged from $3.9 \mathrm{fg} / \mathrm{L}(2,3,7,8-\mathrm{TCDD})$ to 1.3

$271 \times 10^{4} \mathrm{fg} / \mathrm{L}(2,7 / 2,8-\mathrm{DiCDD})$ and from $0.6(2,3,7,8-\mathrm{TCDD})$ to $1.7 \times 10^{4} \mathrm{fg} / \mathrm{L}(2,7 / 2,8-\mathrm{DiCDD})$ in

272 porewater. Fractions of equilibrium reached for each analyte $\left(\mathrm{f}_{\mathrm{EQ}} \mathrm{s}\right)$, used for calculating

273 corresponding dissolved concentrations, are reported in Table S3, while PCDD/F concentrations

274 determined in the three different sizes of porewater PE are reported in Table S4. We divided

275 PCDD/F concentrations in PE deployed in the water column by those of PE samplers tumbled

276 with sediments in the laboratory to obtain deep water - porewater activity gradients (Fig. S4). 
277 At all sites, low MW PCDD/Fs (mono- through tetra-CDD/Fs) exhibited activity gradients of

278 approximately one (mean of 2.10) that varied in direction (range of 0.45 to 12.6 ), implying that,

279 on average, there was little net flux between Newark Bay porewater and deep water for low MW

280 PCDD/Fs, similar to PCDD/F fluxes at other locations (Cornelissen et al., 2008). At sampling

281 stations where high MW PCDD/Fs (penta- through octa-CDD/Fs) were detected, activity

282 gradients were primarily in the direction of the deep water (mean of 0.35 , range of 0.04 to 1.15 ),

283 indicating porewater is a potential source of these compounds to the overlying water column.

284 The only PCDD/F that had an activity gradient in the direction of the porewater at all stations

285 was 2,7/2,8-DiCDD. As discussed elsewhere (Friedman et al., 2012), this is possibly due to on-

286 going formation of 2,7/2,8-DiCDD from triclosan within Newark Bay. Overall, activity gradients

287 suggested low MW PCDD/Fs were well mixed between the porewater and water column,

288 whereas high MW PCDD/Fs were still potentially being released to the water column. These

289 results are consistent with only low MW congeners being taken up in filter feeders living at the

290 sediment-water interface, and the presence of high MW congeners in deposit feeders living

291 within the sediment.

292

293 Activity gradients should be interpreted in the context of uncertainties related to the

294 substitution of $1 / 2$ the analytical detection limit for non-detects and adjustments to deep water

295 concentrations based on PRCs, however. We assumed the following relative uncertainties: 100\%

296 for PE concentrations with non-detects replaced; $1-\mathrm{f}_{\mathrm{EQ}}$ for the equilibrium correction for each

297 deep water PE sampler (Friedman et al., 2012); relative standard deviation of PCDD/F

298 concentration in porewater PEs (Table S4). Resulting uncertainties were between $11 \%$ and

$299200 \%$ for the activity gradients (mean of $88 \%$; see the SI for uncertainty calculations). This is in 
300 addition to analytical uncertainty (shown in error bars in Fig. S4). The high end of this

301 uncertainty range generally only applies to gradients with non-detects replaced, identified with

302 asterisks in Fig. S4, or high MW congeners (2,3,7,8-TCDD through OCDD). The lower average

303 gradient uncertainty of $48 \%$ for low MW congeners supports our assertion that low MW

304 PCDD/Fs are well-mixed within the Bay, but the greater uncertainties for higher MW PCDD/Fs

305 make it difficult to draw conclusions regarding the direction and magnitudes of their gradients.

307 Estimating biota PCDD/F uptake and sediment-specific $K_{B C} S$

308 To assess where native tissues received the majority of their PCDD/F exposures, we

309 calculated lipid-based tissue concentrations of PCDD/Fs based on partitioning from sediment

310 OC, sediment $\mathrm{OC}$ and $\mathrm{BC}$, porewater PE, and deep water PE. We compared these concentrations

311 to those measured directly in Newark Bay biota (Fig. 2), but only for stations where more than

312 one congener was detected in tissues (the AK, the KVK, and the MB). The comparison

313 discussion is only for congeners detected in sediments, deep water, porewater, and tissues

314 concurrently at a given site (i.e., congeners with only 2 or 3 chlorines).

316 In the AK, where only deposit-feeders were collected, tissue concentrations calculated

317 from OC-water partitioning $\left(\mathrm{C}_{\text {lip,OC }}\right)$ overestimated $\mathrm{C}_{\text {lip }}$ (by $7 \times$ on average), while those from

318 OC+BC-water partitioning $\left(\mathrm{C}_{\text {lip }, \mathrm{OC}+\mathrm{BC}}\right)$ underestimated $\mathrm{C}_{\text {lip }}$ (by $4 \mathrm{x}$ on average) (Fig. 2a).

319 Concentrations calculated from porewater and deep water PE both underestimated $\mathrm{C}_{\text {lip }}$, but not

320 by as much as $\mathrm{C}_{\text {lip,OC+BC }}$. Tissue concentrations calculated from porewater $\mathrm{PE}\left(\mathrm{C}_{\text {lip,PEpw }}\right)$ were

321 underestimated $\mathrm{C}_{\text {lip }}$ by $1.6 \mathrm{x}$ on average, while those calculated from deep water PE $\left(\mathrm{C}_{\text {lip,PEdw }}\right)$ 
322 underestimated $\mathrm{C}_{\text {lip }}$ by $2.8 \mathrm{x}$. Results for the $\mathrm{AK}$ suggest porewater PE were the best predictors of

323 deposit-feeding tissue concentrations.

324

325

In both the $\mathrm{KVK}$ and $\mathrm{MB}$, where only filter-feeders were collected, $\mathrm{C}_{\text {lip,OC }}$ again

overestimated $\mathrm{C}_{\text {lip }}$ (by $3.8 \mathrm{x}$ on average), while $\mathrm{C}_{\text {lip,OC+BC }}$ again underestimated $\mathrm{C}_{\text {lip }}$ (by $13 \mathrm{x}$ on

327 average) (Figs. 2b and 2c). As with AK deposit feeders, concentrations calculated from

328 porewater and deep water $\mathrm{PE}$ underestimated $\mathrm{C}_{\text {lip }}$, but not by as much as $\mathrm{C}_{\text {lip,OC+BC }}$ (by $3.1 \mathrm{x}$ and

$3293.8 x$, respectively). Results for the KVK and MB also suggest porewater PE was the best

330 predictor of filter-feeding tissue PCDD/F concentrations, and that in general PE samplers are

331 better at estimating biota concentrations than traditional sediment equilibrium partitioning

332 methods.

Several high-MW congeners were detected in the sediments of all three sites, but in

335 tissues were only detected in deposit-feeders from the AK. High-MW PCDD/Fs were not

336 detected in porewater (except for OCDD in the AK) or in deep water. The lack of high-MW

337 PCDD/F uptake in filter-feeders suggests porewater/deep water filtration are more important

338 than particle ingestion, as might be expected from previous studies (Lohmann et al., 2004;

339 McLeod et al., 2008).

The use of literature $K_{\mathrm{BC}} \mathrm{S}$ (Lambert, 2010), determined with sediment from an adjacent

342 field site but at deeper depths, resulted in vast under-predictions of bioaccumulation for

$343 \mathrm{PCDD} / \mathrm{Fs}$ due to underestimation of dissolved concentrations. This observation is consistent with

344 previous studies showing that the utility of $K_{\mathrm{BC}}$ is sediment-specific (Arp et al., 2009; Hawthorne 
345 et al., 2007b), and further shows that even sediments from nearby locations but deeper depths,

346 where BC is likely older and qualitatively different, can exhibit substantially different HOC-

347 binding characteristics. Werner et al. (2010) suggested that PCB sorption to BC at low

348 concentrations is linear (i.e., $\mathrm{n}=1$ in eq. 5), but we find that lipid concentrations are instead

349 overestimated when linear sorption is assumed (e.g., using Lambert et al.'s $K_{\mathrm{BC}}$ values with n=1

350 in eq. 5 results in $\mathrm{C}_{\text {lip }}$ overestimates of 3.8x). Thus, in the present study, we derived sediment and

351 depth-specific $K_{\mathrm{BC}}$ from mean measured sediment concentrations and dissolved porewater

352 concentrations across sites. We then used these sediment-specific $K_{\mathrm{BC}}$ to estimate $\mathrm{C}_{\text {lip }}$ at

353 individual sites, as above. Field $K_{\mathrm{BC}}$ were determined only for congeners detected in both

354 porewater PE and sediments at three or more sites (i.e., 2,7/2,8-DiCDD, 2,4,8-TriCDF, and

355 2,3,7-TriCDD), and were calculated for Freundlich coefficients of $n=0.6,0.7$, and 0.8 (Table

356 1). All sediment-specific $K_{\mathrm{BC}}$ sere lower in value than those of Lambert, in some instances by

357 more than an order of magnitude (e.g., 2,3,7-TriCDD). Sediment-specific $K_{\mathrm{BC}}$ improved

$358 \mathrm{C}_{\text {lip }, \mathrm{OC}+\mathrm{BC}}$ estimates of $\mathrm{C}_{\text {lip }}$ by $2-87$ fold. For example, in the $\mathrm{AK}, \mathrm{C}_{\text {lip }, \mathrm{OC}+\mathrm{BC}}$ determined using

359 sediment-specific $\mathrm{K}_{\mathrm{BC}} \mathrm{s}$ was a factor of 1.1 higher than $\mathrm{C}_{\text {lip }}$ (compared to 1.6x lower for

360 porewater $\mathrm{PE}$ ), and in the $\mathrm{KVK}$ and $\mathrm{MB}, \mathrm{C}_{\text {lip, } \mathrm{OC}+\mathrm{BC}}$ determined using sediment-specific $\mathrm{K}_{\mathrm{BC}} \mathrm{S}$

361 was, on average, $4 \mathrm{x}$ lower than $\mathrm{C}_{\text {lip }}$ (compared to $3.1 \mathrm{x}$ lower for porewater $\mathrm{PE}$ ).

362

Though $\mathrm{C}_{\text {lip,OC+BC }}$ from sediment-specific $K_{\mathrm{BC}} \mathrm{S}$ and $\mathrm{C}_{\text {lip,PEpw }}$ were both good predictors of

$364 \mathrm{C}_{\text {lip }}$, each estimator contains uncertainties related to partition coefficients; namely, $K_{\mathrm{PE}-\mathrm{w}} \mathrm{s}$, BAFs,

365 and in the case of $\mathrm{C}_{\text {lip,OC+BC}}, K_{\mathrm{OC}}$ s. We assumed that $K_{\mathrm{PE}-\mathrm{w}}$ and $K_{\mathrm{OC}}$ values had relative

366 uncertainties of $100 \%$, given that both were calculated from $K_{\mathrm{OW}}$, and $K_{\mathrm{OW}} \mathrm{s}$ of these congeners

367 are reported to have a high-end uncertainty of 100\% (Aberg et al., 2008). We assigned a 100\% 
368 relative uncertainty to the conversion of dissolved concentrations to lipid-based from BAFs.

369 Considering these assumptions combined, $\mathrm{C}_{\text {lip,OC+BC }}$ uncertainties are $200 \%$ while $\mathrm{C}_{\text {lip,PEpw }}$

370 uncertainties are $140 \%$; these are in addition to analytical uncertainties (see the SI for uncertainty

371 calculations). Thus, although $\mathrm{C}_{\text {lip, } \mathrm{OC}+\mathrm{BC}}$ and $\mathrm{C}_{\text {lip,PEpw }}$ are roughly equally good predictors of $\mathrm{C}_{\text {lip }}$,

372 we note that the lower relative uncertainty in $\mathrm{C}_{\text {lip,PEpw }} \mathrm{S}$ and their more straightforward

373 determination make them a more practical and reliable option for obtaining site-specific

374 estimates of $\mathrm{C}_{\text {lip. }}$

375

376 Implications for use of PE to predict biota uptake in the field

377 In the present study, we predicted PCDD/F lipid concentrations in deposit feeders within

378 an average factor of 1.6 (range 1.1 - 3.8) using porewater PEs and BAFs, while in a previous

379 study comparing PCB uptake by Nereis virens to uptake in PE in the laboratory (Friedman et al.,

380 2009), we estimated PCB uptake within an average factor of 0.99 (range 0.06 - 3.0) using

381 porewater PE and BAFs. Collectively, this is evidence that PE samplers used to measure

382 porewater can provide consistently more reliable estimates of $\mathrm{C}_{\text {lip }}$ for deposit feeders in both the

383 laboratory and the field compared to the range of estimates observed from sediment equilibrium

384 partitioning.

385

In the present study, however, there were a number of PCDD/Fs found in tissue but not

387 porewater, particularly high MW congeners in AK deposit feeders, suggesting these congeners

388 are not taken up by diffusion from porewater. If $\mathrm{C}_{\text {lip,PEpw }} / \mathrm{C}_{\text {lip }}$ is plotted against $\log \mathrm{K}_{\mathrm{Ow}}$ for

$389 \mathrm{PCDD} / \mathrm{F}$ congeners detected in both phases for AK tube worms, a slight decreasing trend in the

390 ratio is observed with increasing $\mathrm{K}_{\mathrm{OW}}$, though the relationship is not statistically significant at 
$391 \alpha=0.05$ (Fig. 3). Also included in this plot are results from our previous study with PCBs

392 (Friedman et al., 2009), which display similar behavior, but with a steeper decreasing trend that

393 is statistically significant $(\mathrm{p}<0.001)$. If the two datasets are combined, the overall decrease with

$394 \mathrm{~K}_{\mathrm{OW}}$ is significant $(\mathrm{p}=0.01$ ), and implies that biota take up greater concentrations of high MW

395 HOCs than dictated by the chemical activity of their surroundings (i.e., porewater), most likely

396 via ingestion. The magnitude of negative slope tends to taper off at higher $\mathrm{K}_{\mathrm{OW}}$, suggesting that

397 at a given hydrophobicity, ingestion of particle-associated HOCs outweighs partitioning from

398 porewater in governing biota uptake. From the combined data in Fig. 3, this switch from

399 porewater control to ingestion dominance appears to happen between $\log \mathrm{K}_{\mathrm{OW}} 6$ and 7. Similar

400 results have been found in other studies, though the switch may take place at lower $\mathrm{K}_{\mathrm{OwS}}$ in

401 different systems (e.g., at $\log \mathrm{K}_{\mathrm{Ow}}$ of 5.8 for uptake of PCBs in freshwater oligochaetes (Sun et

402 al., 2009)). Benthic organisms, particularly deposit feeders, can have high levels of surfactants in

403 the gut (Mayer et al., 1997); this may contribute to higher levels of high MW PCDD/Fs in tissue

404 compared to PE. Additionally, though measures were taken to remove particles from tissue

405 extracts, it is possible that some remained, which might contribute to higher levels of high MW

$406 \mathrm{PCDD} / \mathrm{Fs}$ in tissues.

Our porewater concentration results suggest that up to $62 \%$ of deposit feeder tissue

409 concentrations can be attributed to equilibrium with porewater. Others using a biodynamic model

410 (McLeod et al., 2008; McLeod, 2007) have estimated that deposit-feeding clams receive even

411 less ( 10\%) of their HOC body burden from porewater, and showed that HOC body burdens in

412 these organisms more closely resemble congener profiles in sediment, rather than porewater.

413 Hence, we emphasize that while PE can be more useful than sediment geochemistry in predicting 
414 correlated biota concentrations, their use does not imply that all HOCs are taken up through

415 diffusive water-biota partitioning. Passive samplers may be less useful in predicting tissue

416 concentrations of the more hydrophobic HOCs limited by diffusive kinetics in deposit feeders.

418 We also note that only two species of biota were collected, providing a limited range of

419 biodiversity for both feeding modes. These two species represent the majority of the diversity

420 observed during sampling, however. The limited range is likely due to frequent navigational

421 dredging and sustained industrial traffic within Newark Bay, in addition to sediment

422 contamination. Thus, results may deviate for other species, and further studies would help

423 determine whether relationships presented here can be generalized.

Conclusion

PE samplers provide more accurate estimates of biota concentrations of PCDD/Fs in the

427 Newark Bay field than traditional sediment equilibrium partitioning methods. The traditional

$428 K_{\mathrm{OC}}$ partitioning model consistently overestimated biota PCDD/F uptake, by a factor of 4-7

429 times. In contrast, estimates based on $K_{\mathrm{OC}}$ and $K_{\mathrm{BC}}$ together consistently underestimated biota

430 PCDD/F uptake, by a factor of 4-13 times, even though $K_{\mathrm{BC}} \mathrm{s}$ initially employed were determined

431 with sediment from an adjacent location. When we used porewater concentrations to find

432 sediment- and depth-specific $K_{\mathrm{BC}} \mathrm{s}$, we improved predictions of biota PCDD/F uptake estimates.

433 Given the additional laboratory time and uncertainty involved in determining sediment-specific

$434 K_{\mathrm{BCS}}$, however, we recommend taking direct measurements of porewater concentrations using

$435 \mathrm{PE}$ and eliminating sediment measurements altogether as a more practical, efficient approach for

436 site-specific determinations. Careful attention needs to paid to equilibrium conditions and the 
437 fact that kinetically-limited HOCs are susceptible to underestimates, though. There is little

438 diffusive exchange of low MW PCDD/Fs between the porewater and water column in Newark

439 Bay, while there is more uncertainty surrounding the exchange of high MW PCDD/Fs.

440 Equilibrium across the sediment-water interface for low MW congeners is consistent with

$441 \mathrm{PCDD} / \mathrm{F}$ body burdens observed in filter feeders.

443 ACKNOWLEDGEMENTS

444 We thank Robert Chant (Rutgers University) and Christopher Sommerfield (University of

445 Delaware) for time aboard the R/V Caleta, use of data and sediment samples, and insightful

446 discussions, as well as Eric Stern, Nicole Bujalski, and Mark Reiss (U.S. EPA) for time aboard

447 the R/V Kenneth Biglane and assistance with sampling. Mark Cantwell (U.S. EPA) assisted with

448 instrumental analysis and Julia Sullivan (URI-GSO) with OC and BC analysis. We thank

449 anonymous reviewers for constructive comments. This work was supported by the Hudson River

450 Foundation through grant 07/007A to R. Lohmann and GF/01/09 to C. Friedman.

452 Supplementary Information

453 The supporting information includes tables and figures relating to sediment organic and

454 black carbon content, sediment and PE PCDD/F concentrations, and porewater-deep water

455 PCDD/F gradients, as well as details regarding methods. 
US EPA, USACE, NJ DEP, NJ DOT. Lower Passaic River Restoration Project

$<$ http://www.ourpassaic.org $>$.

Aberg, A., MacLeod, M., Wiberg, K., 2008. Physical-chemical property data for dibenzo-pdioxin (DD), dibenzofuran (DF), and chlorinated DD/Fs: A critical review and recommended values. J. Phys. Chem. Ref. Data 37, 1997-2008. Accardi-Dey, A., Gschwend, P.M., 2002. Assessing the combined roles of natural organic matter and black carbon as sorbents in sediments. Environ. Sci. Technol. 36, 21-29. Accardi-Dey, A., Gschwend, P.M., 2003. Reinterpreting literature sorption data considering both absorption into organic carbon and adsorption onto black carbon. Environ. Sci. Technol. 37, 99106. Adams, R.G., Lohmann, R., Fernandez, L.A., Macfarlane, J.K., Gschwend, P.M., 2007. Polyethylene devices: Passive samplers for measuring dissolved hydrophobic organic compounds in aquatic environments. Environ. Sci. Technol. 41, 1317-1323.

Arp, H.P.H., Breedveld, G.D., Cornelissen, G., 2009. Estimating the in situ sediment-porewater distribution of PAHs and chlorinated aromatic hydrocarbons in anthropogenic impacted sediments. Environ. Sci. Technol. 43, 5576-5585.

Booij, K., Smedes, F., van Weerlee, E.M., 2002. Spiking of performance reference compounds in low density polyethylene and silicone passive water samplers. Chemosphere 46, 1157-1161.

Burgess, R.M., Berry, W.J., Mount, D.R., DiToro, D.M., 2013. Mechanistic sediment quality guidelines based on contaminant bioavailability: Equilibrium partitioning Sediment Benchmarks (ESBs). Environ. Toxicol. Chem. 32, 102-114.

Caplow, T., Schlosser, P., Ho, D.T., Santella, N., 2003. Transport dynamics in a sheltered estuary and connecting tidal straits: $\mathrm{SF}_{6}$ tracer study in New York Harbor. Environ. Sci. Technol. 37, 5116-5126.

CARP, 2007. Data Archive: Water, Sediment and Biota Data collected from 1999-2003. Hudson River Foundation, New York, NY. CD-ROM.

Cho, Y.-M., Ghosh, U., Kennedy, A.J., Grossman, A., Ray, G., Tomaszewski, J.E., Smithenry, D.W., Bridges, T.S., Luthy, R.G., 2009. Field application of activated carbon amendment for insitu stabilization of polychlorinated biphenyls in marine sediment. Environ. Sci. Technol. 43, 3815-3823.

Choi, Y., Cho, Y.-M., Luthy, R.G., 2013. Polyethylene-water partition coefficients for parentand alkylated-polycyclic aromatic hydrocarbons and polychlorinated biphenyls. Environ. Sci. Technol. Article ASAP.

Cornelissen, G., Wiberg, K., Broman, D., Arp, H.P.H., Persson, Y., Sundqvist, K., Jonsson, P., 2008. Freely dissolved concentrations and sediment-water activity ratios of PCDD/Fs and PCBs in the open Baltic Sea. Environ. Sci. Technol. 42, 8733-8739.

DeWit, C., Jansson, B., Bergek, S., Hjelt, M., Rappe, C., Olsson, M., Andersson, O., 1995. Polychlorinated dibenzo- $p$-dioxin and polychlorinated dibenzofuran levels and patterns in fish and fish-eating wildlife in the Baltic Sea. Chemosphere 25, 185-188.

DiToro, D.M., Zarba, C.S., Hansen, D.J., Berry, W.J., Swartz, R.C., Cowan, C.E., Pavlou, S.P., Allen, H.E., Thomas, N.A., Paquin, P.R., 1991. Technical Basis for Establishing Sediment Quality Criteria for Nonionic Organic Chemicals Using Equilibrium Partitioning. Environ. Toxicol. Chem. 10, 1541-1583. 
Fernandez, L.A., Macfarlane, J.K., Tcaciuc, A.P., Gschwend, P.M., 2009. Measurement of freely dissolved PAH concentrations in sediment beds using passive sampling with low-density

502 polyethylene strips. Environ. Sci. Technol. 43, 1430-1436.

503 Friedman, C.L., Burgess, R.M., Perron, M.M., Cantwell, M.G., Ho, K.T., Lohmann, R., 2009.

504 Comparing polychaete bioaccumulation and passive sampler uptake to assess the effects of sediment resuspension on PCB bioavailability. Environ. Sci. Technol. 43, 2865-2870. Friedman, C.L., Cantwell, M.G., Lohmann, R., 2012. Passive sampling provides evidence for Newark Bay as a source of PCDD/Fs to the New York/New Jersey atmosphere. Environ. Toxicol. Chem. 31, 253-261. the dilute sedimentary soot phase: Implications for PAH speciation and bioavailability. Environ. Hammes, K., Schmidt, M.W.I., Smernik, R.J., Currie, L.A., Ball, W.P., Nguyen, T.H., Louchouarn, P., Houel, S., Gustafsson, O., Elmquist, M., Cornelissen, G., Skjemstad, J.O., Masiello, C.A., Song, J., Peng, P., Mitra, S., Dunn, J.C., Hatcher, P.G., Hockaday, W.C., Smith, D.M., Hartkopf-Froeder, C., Boehmer, A., Luer, B., Huebert, B.J., Amelung, W., Brodowski, S., Huang, L., Zhang, W., Gschwend, P.M., Flores-Cervantes, D.X., Largeau, C., Rouzaud, J.N., Rumpel, C., Guggenberger, G., Kaiser, K., Rodionov, A., Gonzalez-Vila, F.J., Gonzalez-Perez, J.A., de la Rosa, J.M., Manning, D.A.C., Lopez-Capel, E., Ding, L., 2007. Comparison of quantification methods to measure fire-derived (black/elemental) carbon in soils and sediments using reference materials from soil, water, sediment and the atmosphere. Global Biogeochem. Cycles 21, 1-18.

Hawthorne, S.B., Azzolina, N.A., Neuhauser, E.F., Kreitinger, J.P., 2007a. Predicting bioavailability of sediment polycyclic aromatic hydrocarbons to Hyalella azteca using equilibrium partitioning, supercritial fluid extraction, and pore water concentrations. Environ. Sci. Technol. 41, 6297-6304.

Hawthorne, S.B., Grabanski, C.B., Miller, D.J., 2006. Measured partitioning coefficients for parent and alkyl polycyclic aromatic hydrocarbons in 114 historically contaminated sediments: Part 1. KOC values. Environ. Toxicol. Chem. 25, 2901-2911. Hawthorne, S.B., Grabanski, C.B., Miller, D.J., 2007b. Measured partition coefficients for parent and alkyl polycyclic aromatic hydrocarbons in 114 historically contaminated sediments: Part 2. Testing the $\mathrm{K}_{\mathrm{OC}} \mathrm{K}_{\mathrm{BC}}$ two carbon-type model. Environ. Toxicol. Chem. 26, 2505-2516. Huckins, J.N., Petty, J.D., Lebo, J.A., Almeida, F.V., Booij, K., Alvarez, D.A., Clark, R.C., Mogensen, B.B., 2002. Development of the permeability/performance reference compound approach for in situ calibration of semipermeable membrane devices. Environ. Sci. Technol. 36, 85-91.

Huckins, J.N., Tubergen, M.W., Manuweera, G.K., 1990. Semipermeable membrane devices containing model lipid: A new approach to monitoring the bioavailability of lipophilic contaminants and estimating their bioconcentration potential. Chemosphere 20, 533-552. Lambert, M., 2010. The role of black carbon in the sorption of polychlorinated dibenzo- $p$ dioxins and dibenzofurans at the Diamond Alkali Superfund site, Newark Bay, NJ, Oceanography. University of Rhode Island Graduate School of Oceanography, MS Thesis, Narragansett.

Lambert, M., Friedman, C., Luey, P., Lohmann, R., 2011. Role of black carbon in the sorption of polychlorinated dibenzo- $p$-dioxins and dibenzofurans at the Diamond Alkali Superfund site, Newark Bay, New Jersey. Environ. Sci. Technol. 45, 4331-4338. 
Lohmann, R., Burgess, R.M., Cantwell, M.G., Ryba, S.A., MacFarlane, J.K., Gschwend, P.M., 2004. Dependency of polychlorinated biphenyl and polycyclic aromatic hydrocarbon bioaccumulation in Mya arenaria on both water column and sediment bed chemical activities. Environ. Toxicol. Chem. 23, 2551-2562.

Lohmann, R., MacFarlane, J.K., Gschwend, P.M., 2005. Importance of black carbon to sorption of native PAHs, PCBs, and PCDDs in Boston and New York, Harbor sediments. Environ. Sci. Technol. 39, 141-148.

Luthy, R.G., Aiken, G.R., Brusseau, M.L., Cunningham, S.D., Gschwend, P.M., Pignatello, J.J., Reinhard, M., Traina, S.J., Weber, W.J., Westall, J.C., 1997. Sequestration of hydrophobic organic contaminants by geosorbents. Environ. Sci. Technol. 31, 3341-3347.

Mayer, L.M., Schick, L.L., Self, R.F.L., Jumars, P.A., Findlay, R.H., Chen, Z., Sampson, S., 1997. Digestive environments of benthic macroinvertebrate guts: Enzymes, surfactants and dissolved organic matter. J. Mar. Res. 55, 785-812.

Mayer, P., Vaes, W.H.J., Wijnker, F., Legierse, K., Kraaij, R.H., Tolls, J., Hermens, J.L.M., 2000. Sensing dissolved sediment porewater concentrations of persistent and bioaccumulative pollutants using disposable solid-phase microextraction fibers. Environ. Sci. Technol. 34, $5177-$ 5183.

McLeod, P.B., Luoma, S.N., Luthy, R.G., 2008. Biodynamic modeling of PCB uptake by Macoma balthica and Corbicula fluminea from sediment amended with activated carbon. Environ. Sci. Technol. 42, 484-490.

McLeod, P.B.v.d.H.-G., M.J.; Luoma, S.N.; Luthy, R.G., 2007. Biological uptake of polychlorinated biphenyls by Macoma bathica from sediment amended with activated carbon. Environ. Toxicol. Chem. 26, 980-987.

Morgan, E., Lohmann, R., 2008. Detecting air-water and surface-deep water gradients of PCBs using polyethylene passive samplers. Environ Sci Technol. 42, 7248-7253.

Muijs, B., Jonker, M., 2009. Temperature-dependent bioaccumulation of polycyclic aromatic hydrocarbons. Environ. Sci. Technol. 43, 4517-4523.

Pickard, S.W., Clarke, J.U., 2008. Benthic bioaccumulation and bioavailability of polychlorinated dibenzo- $p$-dioxins/dibenzofurans from surficial Lake Ontario sediments. J. Great Lakes Res. 34, 418-433.

Rappe, C., Bergqvist, P.-A., Kjeller, L.-O., Swanson, S., Belton, T., Ruppel, B., Lockwood, K., Kahn, P.C., 1991. Levels and patterns of PCDD and PCDF contamination in fish, crabs, and lobsters from Newark Bay and the New York Bight. Chemosphere 2, 239-266.

Schneider, A.R., Paolicchi, A., Baker, J.E., 2006. The use of solid-phase microextraction to rapidly measure dissolved PCBs in natural waters. Intern. J. Environ. Anal. Chem. 86, 789-803. Sun, X., Werner, D., Ghosh, U., 2009. Modeling PCB mass transfer and bioaccumulation in a freshwater oligochaete before and after amendment of sediment with activated carbon. Environ. Sci. Technol. 43, 1115-1121.

Vinturella, A.E., Burgess, R.M., Coull, B.A., Thompson, K.M., Shine, J.P., 2004. Use of passive samplers to mimic uptake of polycyclic aromatic hydrocarbons by benthic polychaetes. Environ. Sci. Technol. 38, 1154-1160.

Werner, D., Hale, S.E., Ghosh, U., Luthy, R.G., 2010. Polychlorinated biphenyl sorption and availability in field-contaminated sediments. Environ. Sci. Technol. 44, 2809-2815. Xia, G.S., 1998. Sorption behavior of nonpolar organic chemicals on natural sorbents. PhD Dissertation, Johns Hopkins University, Baltimore MD. 


\section{TABLES}

593 Table 1. Mean sediment-specific polychlorinated dibenzo- $p$-dioxin and dibenzofuran (PCDD/F)

$594 \log$ black carbon - water partition coefficients $\left(\log \mathrm{K}_{\mathrm{BC}} \mathrm{s}\right)$ for all of Newark Bay.

\begin{tabular}{|c|c|c|c|c|c|c|}
\hline \multirow{2}{*}{$\mathrm{PCDD} / \mathrm{F}$} & \multirow{2}{*}{$\log K_{\mathrm{OW}}$} & \multirow{2}{*}{$\log K_{\mathrm{OC}}$} & \multicolumn{3}{|c|}{ Field-derived $\log K_{\mathrm{BC}}$} & Lambert [21] $\log K_{\mathrm{BC}}$ \\
\cline { 4 - 7 } & & & $n=0.6$ & $n=0.7$ & $n=0.8$ & $n=0.7$ \\
\hline 2,7/2,8-DiCDD & 5.59 & 5.30 & $5.18 \pm 0.34$ & $5.68 \pm 0.34$ & $6.19 \pm 0.33$ & 6.38 \\
\hline $2,4,8$-TriCDF & 5.74 & 5.45 & $5.13 \pm 0.32$ & $5.73 \pm 0.30$ & $6.34 \pm 0.32$ & 5.89 \\
\hline 2,3,7-TriCDD & 6.09 & 5.79 & $4.90 \pm 0.12$ & $5.59 \pm 0.08$ & $6.28 \pm 0.05$ & 6.87 \\
\hline
\end{tabular}

FIGURES

597 Figure 1. Newark Bay, surrounding water bodies, sampling locations (white circles), and the 598 Diamond Alkali Superfund site.

600 Figure 2. Ratios of estimated versus measured lipid-normalized polychlorinated dibenzo- $p$ 601 dioxin and dibenzofuran (PCDD/F) biota concentrations. Biota concentrations were estimated 602 based on PCDD/F partitioning between biota and sediment organic carbon (OC), sediment OC 603 and black carbon (BC), polyethylene (PE) in porewater, and PE in deep water in a) Arthur Kill 604 (tube worms), b) Kill van Kull (clams), and c) mid-Bay (clams). Also shown are ratios of biota 605 concentrations estimated from sediment OC and BC calculated using sediment-specific black 606 carbon - water partition coefficients $\left(K_{\mathrm{BC}}\right)$ to those directly measured.

608 Figure 3. Ratio of lipid-based biota concentrations estimated from porewater PE to those 609 measured directly in deposit-feeders collected from the Arthur Kill in the current study 610 (PCDD/Fs) or from a laboratory bioaccumulation test in a previous study (PCBs) versus log

$611 \mathrm{~K}_{\mathrm{Ow}}$. The linear best fit for the PCDD/F dataset is $\mathrm{y}=-0.0064 \mathrm{x}+0.56$, but the regression is not 612 significant $(\mathrm{p}=0.96)$. The linear best fit for the PCB data is $y=-1.4 \mathrm{x}+10$ with a regression 
613 significance of $\mathrm{p}<0.001$. The linear best fit for the entire dataset is $y=-0.57 x+4.4$ with an $r^{2}$ of 6140.31 with a regression significance of $p=0.01$. 